\title{
Computing Academics into New Age Applied Science Programs and Fields Emphasizing Trend on Animation and Multimedia Technology-An Investigation of Indian Private Universities
}

\author{
P. K. Paul ${ }^{1}$, P. S. Aithal ${ }^{2}$, A. Bhuimali ${ }^{3}$ \\ 1*Raiganj University (RGU), West Bengal, India \\ ${ }^{2}$ Vice Chancellor, Srinivas University, Karnataka, India \\ ${ }^{3}$ Vice Chancellor, Raiganj University, West Bengal, India \\ *Corresponding Author: pkpaul.infotech@gmail.com
}

Available online at: www.isroset.org

Received 06/Dec/2017, Revised 22/Dec/2017, Accepted 25/Jan/2018, Online 28/Feb/2018

\begin{abstract}
The world is changing rapidly and for this information and technology playing a leading role. Computing is the vital driving force for the information and technological affairs which include collection, selection, organization, processing, management and dissemination of information. Initially the field computing was started with the domain Computer Science and then gradually many other subjects and allied areas have been developed viz. Computer Engineering, Computer Systems, Computing, Computer Application, Software Engineering etc. Moreover in a different track i.e. on 'Information Centric' many other subjects have been developed and widely used viz. Information Technology, Informatics, Information Systems, Information Science, Knowledge Management etc. Even the advancement of interdisciplinary research leads many new merged and inter-connected areas and fields viz. Geo Information Science, Health Information Science etc. The areas of computing and information are also called as Information Sciences or Computing and Information Sciences as well. Among the sub fields and areas within the field is Multimedia Technology and it is important and emerging in Indian Universities as well. This paper is a conceptual and theoretical one; which is governed by the aim of emerging Multimedia Technology programs in Indian Private Universities.
\end{abstract}

Keywords - Information Technology, IT, Universities, Private Universities, India, HEIs, Multimedia Technology, Emerging Degree

\section{INTRODUCTION}

The field of Information Technology is most emerging and rapidly growing there are lot of development undertaken in last few decades. Initially the journey was started with the domain of Computing track and at first with 'Computer Science' though gradually universities were moved on other concentrations due to requirement in the industries and organizations and in this context the field of Computing/ Computer Application has been developed [1], [5], [10]. However in India, the term 'Computer Application' is mainly conceptualized and started as an academic program with leading to BCA and MCA degree. Computer Engineering is another domain focused with the designing and development of Computers or Computer Systems [2], [3], [11]. Though the market demand and need of the information affairs in the industry has lead the development of new subject called 'Information Technology'. It is worthy to note that it is called as IT and mainly consist with the sub fields and components viz. Database Technology, Network Technology, Multimedia Technology, Software Technology etc [4], [5], [10]. Hence the domain Information Technology deals various other components apart from Software Technology which is an important components in other allied and related subjects (mainly Computer Track) [6], [7], [12]. The area of Multimedia Technology within IT no doubt emerging and valuable due to its needs and growing uses in Indian academics previously it was treated as a area and components of IT but the latest development in the education systems, components leads the development and as a result Multimedia Technology is become a field of study and academic program in the universities emphasizing private universities [8], [9], [12]. The paper focuses how, why and where Multimedia Technologies and allied branch become an important domain and field of study.

\section{OBJECTIVE AND METHODS}

The present paper is conceptual in nature and deals with the various aim and objectives which include but not limited to the following - 
- To know about the basics of Computing and Information field including Information Technology.

- To learn about the nature of Computing and allied fields and domains including their different focuses.

- To dig out Indian Information Technology domain which is practiced and available in the Universities.

- To learn about the basics of Higher Education Systems in India with reference to the IT and Computing education.

- To learn about the Multimedia Technology as an emerging domain within Information Technology and programs on this with case on Indian Private Universities.

- To learn more about micro and super specialty areas within Multimedia Technologies including Game Designing, Visual Effects, Animation with emphasis on its educational programs in Indian Private Universities.

The paper entitled 'Computing Academics into New Age Applied Science Programs and Fields Emphasizing Trend on Animation and Multimedia Technology-An Investigation of Indian Private Universities' is conceptual in nature and thus mix mode research methodologies have been used which includes the review of literature; mainly books and journals for gathering knowledge in the areas of Computing and Information Technologies including its nature and basics, scope and differences among the areas, available educational programs in the field with special reference to the emerging areas as a field of study focused on Multimedia Technologies etc. Hence to learn about the latest programs in the field of Multimedia Technologies a web-survey has been conducted and here the core URL considered as UGC Site (i.e. https://www.ugc.ac.in/privatuniversity.aspx). The study conducted during the period of October, 2017 to December, 2017 only and thus only the universities reported the programs of study in the areas have been included.

\section{INDIAN ACADEMICS WITH REFERENCE TO INFORMATION \& COMPUTING}

India is a developing nation. In the last few years Indian educational systems, planning and policies have been changed radically. The Indian academia holds different kind of nomenclatures and subjects within the field of information and computing. Traditionally the oldest branch within this is 'Computer Science' and apart from this in India Engineering track is available as merged domain 'Computer Science and Engineering'. Though in applied concentration another new branch has been conceptualized and developed i.e.
'Computer Application'. There are the main subjects and programs within 'Computing' track whereas in 'Information' track few other subjects are available viz. 'Information Technology', 'Information Systems', 'Information Science', 'Informatics', 'Information and Knowledge Management' etc but in India only One subject is available i.e. 'Information Technology'. Though apart from the subjects mentioned above within 'Computing' track few other are also available internationally viz. 'Computing'/ 'Computer Systems' etc. Another important fact is in India this field is also available in two platform i.e. 'Science' and 'Engineering'. The subjects which are available in India mainly available with two track based Degrees i.e. BE/BTech and ME/MTech. Though, the branch Computer Application is offered with BCA and MCA only and exceptionally BSc and MSc [9], [13], [16].

\section{APPLIED SCIENCE \& INFORMATION SCIENCES: NEW DIRECTION}

The broader domain within 'Computer and Information' is Information Science. There are many new subjects and interdisciplinary fields have been generated within this which includes

- Health Information Science,

- Bio Information Science,

- Chemo Information Science,

- Geo Information Science,

- Business Information Science etc.

Moreover the field also received few other components within Information Technology which includes (but not limited to) Database Technology, Multimedia Technology, Network Technology, Communication Technology, Web Technology apart from Software Technology. It is worthy to note that these each components in recent past developed as a branch of study and even emerged field with the degrees leading to Bachelors and Masters one. Even many of these branches are available with BTech and MTech Degrees. For example the degrees are available with BSc/MSc/BTech/MTech-Networking Technology etc. The latest educational model and policies are rising recently as a specialization/ major within the branch of 'Computing and Information/IT' for example MSc-Information Technology (Networking)/ (Database)/ (Web Technology) etc. The same may be also available in other smaller or broader subjects within the field viz. 'Computer Science'/ 'Information Science'. Apart from these another possible/rising move on Engineering and Technology degrees i.e. BTech/MTech [10], [14], [15]. 


\section{Multimedia ANd Allied Technologies: A CASE STUDY}

Multimedia Technology is a broad domain consists with the multimedia systems, animation, graphics, content management systems. The technology combined with the text, audio, video, image, contents, animation etc. Due to the wider applications of the Multimedia Technologies viz. Entertainment, Education, Government, Business, Medicine, Journalism etc the acceptance and role of Multimedia Technologies have been increased in recent past. And internationally the field is become gaining as an important branch of Information and Computing. The international and few Indian universities have started educational programs leading to Bachelors and Masters degrees in the field in different capacity and model viz.

-Full-fledged Degree

-Major

- Concentration

- Specialization

-Minor etc

The present study entitled 'Computing Academics into New Age Applied Science Programs and Fields Emphasizing Trend on Animation and Multimedia Technology-An Investigation of Indian Private Universities' is dedicated to find out the availability of programs in the prescribed field and to recognize Multimedia Technologies as a field of study rather only a component.

India is one of the largest education systems in the world which consist with Colleges, Universities, Research Centres, Autonomous Bodies etc. The University systems further consist with Central University, State University, Private University, Deemed University. The trend of private universities has been increased in recent past and after 2000 . Today as a whole total 279 universities have been established in the areas and among the states holds highest number of universities are include Rajasthan (46), Gujarat (30) and Uttar Pradesh (29).

It is worthy to note that among these universities, significantly a large number of universities have been started Multimedia and Allied Technologies as a program and field of study. As per the study it is noted that 41 universities have started programs in the areas which includes-

- Multimedia

- Animation including 3D etc

-Visual Effects (VFX)

-Game Designing etc
The table: 1 in this respect provides a detail on this i.e. number of universities have Multimedia Technologies as a field of study and number of educational programs offered in different private universities, state wise.

Table: 1-Private Universities and Multimedia/ Allied Technologies as a field of study

\begin{tabular}{|c|c|c|c|c|}
\hline $\begin{array}{l}\text { Serial } \\
\text { No. }\end{array}$ & States & $\begin{array}{c}\text { No. of } \\
\text { Universities }\end{array}$ & $\begin{array}{c}\text { No. } \\
\text { universities } \\
\text { having } \\
\text { Multimedia } \\
\text { Technologies } \\
\text { \& Animation } \\
\text { Programs }\end{array}$ & $\begin{array}{c}\text { No. of } \\
\text { Multimedia } \\
\text { Technologies } \\
\text { \& Animation } \\
\text { Programs }\end{array}$ \\
\hline 1 & $\begin{array}{l}\text { Arunachal } \\
\text { Pradesh }\end{array}$ & 7 & 1 & 4 \\
\hline 2 & Assam & 5 & Nil & Nil \\
\hline 3 & Bihar & 2 & Nil & Nil \\
\hline 4 & Chhattisgarh & 9 & 2 & 4 \\
\hline 5 & Gujarat & 30 & Nil & Nil \\
\hline 6 & Haryana & 20 & 1 & 1 \\
\hline 7 & $\begin{array}{l}\text { Himachal } \\
\text { Pradesh }\end{array}$ & 17 & 1 & 1 \\
\hline 8 & Jharkhand & 7 & Nil & Nil \\
\hline 9 & Karnataka & 14 & 2 & 2 \\
\hline 10 & Meghalaya & 8 & 1 & 2 \\
\hline 11 & Mizoram & 1 & Nil & Nil \\
\hline 12 & $\begin{array}{l}\text { Madhya } \\
\text { Pradesh }\end{array}$ & 24 & 1 & 1 \\
\hline 13 & Maharashtra & 9 & 4 & 5 \\
\hline 14 & Manipur & 1 & Nil & Nil \\
\hline 15 & Nagaland & 3 & Nil & Nil \\
\hline 16 & Odisha & 4 & Nil & Nil \\
\hline 17 & Punjab & 15 & 9 & 18 \\
\hline 18 & Rajasthan & 46 & 5 & 7 \\
\hline 19 & Sikkim & 5 & Nil & Nil \\
\hline 20 & Tripura & 1 & Nil & Nil \\
\hline 21 & Uttar Pradesh & 29 & 9 & 15 \\
\hline 22 & Uttrakhand & 13 & 3 & 4 \\
\hline 23 & West Bengal & 9 & 2 & 3 \\
\hline & Total Grand & 279 & 41 & 66 \\
\hline
\end{tabular}


Table: 2-Private Universities and Multimedia/ Allied Technologies: detailed

\begin{tabular}{|c|c|c|}
\hline Sl. No. & \multicolumn{2}{|c|}{ Private Universities with Multimedia \& Allied Technologies (UG \& Above) } \\
\hline & Universities & Programs \\
\hline \multicolumn{3}{|c|}{ Arunachal Pradesh } \\
\hline 1 & Himalayan University & $\begin{array}{c}\text { BSc-Visual Effects \& Multimedia } \\
\text { (Science 10+2) } \\
\text { MSc-Multimedia \& Animations / Tele } \\
\text { Communication (Relevant)/ } \\
\text { MSc- Visual Effects \& Multimedia (Lateral) }\end{array}$ \\
\hline \multicolumn{3}{|c|}{ Assam } \\
\hline \multicolumn{3}{|c|}{ Absent } \\
\hline \multicolumn{3}{|c|}{ Bihar } \\
\hline \multicolumn{3}{|c|}{ Absent } \\
\hline \multicolumn{3}{|c|}{ Chhattisgarh } \\
\hline 2 & Kalinga University & $\begin{array}{c}\text { BSc- Animation \& VFX } \\
\text { MSc-Animation \& VFX- Any Stream }\end{array}$ \\
\hline 3 & MATS University & $\begin{array}{c}\text { BSc (Animation \& Graphics) } \\
\text { MPhil (Animation) }\end{array}$ \\
\hline \multicolumn{3}{|c|}{ Gujarat } \\
\hline \multicolumn{3}{|c|}{ Absent } \\
\hline \multicolumn{3}{|c|}{ Haryana } \\
\hline 4 & Shree Guru Gobind Singh Tricentenary University & BTech-CSE ( Animation \& Games) \\
\hline \multicolumn{3}{|c|}{ Himachal Pradesh } \\
\hline 5 & Eternal University & BTech-CSE (Computer Animations) \\
\hline \multicolumn{3}{|c|}{ Jharkhand } \\
\hline \multicolumn{3}{|c|}{ Absent } \\
\hline \multicolumn{3}{|c|}{ Karnataka } \\
\hline 6 & CMR University & $\begin{array}{l}\text { BCA (Game \& Mobile App Development)-10+2 } \\
\text { with Math }\end{array}$ \\
\hline 7 & M.S. Ramaiah University of Applied Sciences & M.Des (Computer Animation \& Game Design) \\
\hline \multicolumn{3}{|c|}{ Meghalaya } \\
\hline 8 & Mahatma Gandhi University & $\begin{array}{c}\text { BA (VFX \& Animation) } \\
\text { MA (VFX \& Animation) (Any Degree) }\end{array}$ \\
\hline \multicolumn{3}{|c|}{ Mizoram } \\
\hline \multicolumn{3}{|c|}{ Absent } \\
\hline \multicolumn{3}{|c|}{ Madhya Pradesh } \\
\hline 9 & Jagran Lakecity University & BFA ( Digital Film Making \& VFX) \\
\hline \multicolumn{3}{|c|}{ Maharashtra } \\
\hline 10 & Ajeenkya D.Y. Patil University & BSc-Animation \& VFX) \\
\hline 11 & Amity University & BSc-Animation \& Visual Grapphics \\
\hline 12 & MIT Art Design \& Technology University & B.Design (Animation/ Game Design) \\
\hline 13 & Sandip University & BFA (Animation \& VFX) \\
\hline \multicolumn{3}{|c|}{ Manipur } \\
\hline \multicolumn{3}{|c|}{ Absent } \\
\hline \multicolumn{3}{|c|}{ Nagaland } \\
\hline \multicolumn{3}{|c|}{ Absent } \\
\hline \multicolumn{3}{|c|}{ Odisha } \\
\hline \multicolumn{3}{|c|}{ Absent } \\
\hline \multicolumn{3}{|c|}{ Punjab } \\
\hline 14 & Chandigarh University & $\begin{array}{l}\text { BSc-Animation, VFX \& Gaming (10+2 Any)/ } \\
\text { MSc-Animation \& Multimedia Technology }\end{array}$ \\
\hline
\end{tabular}




\begin{tabular}{|c|c|c|}
\hline 15 & Chitkara University & BSc-Animation (10+2 Any) \\
\hline 16 & C.T University & B. Design (Multimedia) \\
\hline 17 & Desh Bhagat University & $\begin{array}{l}\text { BSc-Animation (Any 10+2) } \\
\text { MSc- Animation (Any Degree) }\end{array}$ \\
\hline 18 & GNA University & $\begin{array}{c}\text { BSc-Animation \& Multimedia } \\
\text { BSc-Game Designing (10+2 Any ) } \\
\text { MSc-Animation \& Multimedia (Any Degree) }\end{array}$ \\
\hline 19 & Guru Kashi University & BSc-Animation \& Visual Effects \\
\hline 20 & Lovely Professional University & $\begin{array}{c}\text { BSc (Design)-Multimedia/ Game Design/ Graphics } \\
\text { (All 10+2 Any) } \\
\text { B.Design (Multimedia/ Graphics) }\end{array}$ \\
\hline 21 & RIMT University & $\begin{array}{l}\text { BSc-Animation \& Multimedia (10+2 Any) } \\
\text { BSc-Graphic Design }\end{array}$ \\
\hline 22 & Sant Baba Bhag Singh University & BSc-Animation \& Multimedia (10+2 Any) \\
\hline \multicolumn{3}{|c|}{ Rajasthan } \\
\hline 23 & Jaipur National University & BSc-Animation \\
\hline 24 & Mody University of Science and Technology & BSc- Multimedia \& Animation \\
\hline 25 & Poornima University & BFA (Animation \& VFX) \\
\hline 26 & Singhania University & $\begin{array}{c}\text { BSc-Animation \& Film Making / Multimedia \& } \\
\text { Animation }\end{array}$ \\
\hline 27 & Sunrise University & BSc-Animation/ PGD in Animation \\
\hline \multicolumn{3}{|c|}{ Sikkim } \\
\hline \multicolumn{3}{|c|}{ Absent } \\
\hline \multicolumn{3}{|c|}{ Tripura } \\
\hline \multicolumn{3}{|c|}{ Absent } \\
\hline \multicolumn{3}{|c|}{ Uttar Pradesh } \\
\hline 28 & Amity University & BFA (Animation) \\
\hline 29 & Bareilly International University & BSc-Multimedia \& Animation (10+2 with Science) \\
\hline 30 & Era University & $\begin{array}{c}\text { BSc-Animation \& Multimedia } \\
\text { BSc-Game Design \& Development/ }\end{array}$ \\
\hline 31 & Galgotias University & $\begin{array}{l}\text { BCA (Animation \& Multimedia)/ } \\
\text { BTech (H)-CSE (Graphics \& Gaming) }\end{array}$ \\
\hline 32 & Invertis University & BTech-CSE (Animation \& VFX) \\
\hline 33 & J.S. University & $\begin{array}{c}\text { BSc-Animation (10+2 Any)/ MSc-Animation } \\
\text { (Related Degree) }\end{array}$ \\
\hline 34 & Maharishi University of Information Technology & $\begin{array}{l}\text { BSc-Animation \& Multimedia/ } \\
\text { MSc-Animation \& Multimedia }\end{array}$ \\
\hline 35 & Sharda University & BSc-Animation \& VFX) \\
\hline 36 & Swami Vivekanand Subharti University & $\begin{array}{c}\text { BFA (Animation) } \\
\text { BSc-Animation } \\
\text { MSc-Animation (Any Degree) }\end{array}$ \\
\hline \multicolumn{3}{|c|}{ Uttarkhand } \\
\hline 37 & Dev Sanskrit Vishwavidyalaya & $\begin{array}{c}\text { BSc-Animation } \\
(10+2 \text { Any })\end{array}$ \\
\hline 38 & Himgiri Zee University & $\begin{array}{l}\text { BSc ( 3D Animation \& Visual Effects) } \\
\text { B.Voc ( 3D Animation \& Visual Effects) }\end{array}$ \\
\hline 39 & University of Petroleum and Energy Studies & $\begin{array}{c}\text { BTech-CSE } \\
\text { (Graphics \& Gaming) } \\
\end{array}$ \\
\hline \multicolumn{3}{|c|}{ West Bengal } \\
\hline 40 & Brainware University & $\begin{array}{l}\text { BA- Multimedia \& Web Development (10+2 Any) } \\
\text { MA-Multimedia \& Web Development }\end{array}$ \\
\hline 41 & Seacom Skills University & MTech-Web \& Game Designing \\
\hline
\end{tabular}


The popularity and need of Multimedia not only lead it as a branch but also reached a level that it is dealing with the concentration and area of Computing programs and area (As Multimedia Technology is a part of Information Technology). The private universities in this regard doing an experiment and educational planning, implementation of offering Multimedia and Allied Technologies with the branch and degree of BTech/MTech. The important affair is the Multimedia is offered within the tag of BTech/MTechCSE as a specialization/ major in the line of western universities. Such as-

- BTech-CSE (Animation)

- BTech-CSE (Graphics)

- BTech-CSE (Computer Animation)

- BTech-CSE (Visual Effects/VFS)

Even the areas are also possible as combined and Indian private universities have done a great job in this regard by the introduction of such innovative programs within the area of Computer Science and Engineering. Table: 3 in this regard provide details of universities including programs/ nomenclatures.

Designing is now a days not only a practicing field but also a field of study, it is important to note that the Degrees normally comes with the Bachelor of Designing and Master of Designing (B. Designing/ M. Designing). In a later phase of its development the specializations were started viz. Interior Designing, Fashion Designing, Product Designing, Communication Designing etc. It is a worthy move by the private universities regarding starting of Multimedia and Allied Technologies within the branch of Designing with a focused model viz.

- B.Design (Computer Graphics)

- B.Design (Multimedia)

Apart from the availability of Multimedia and Allied Technologies in the stream of Technology and Engineering, Designing another move by the private universities is introducing this field within Fine Arts. Fine Arts normally a field concentrated with creative art, visual arts etc for intellectual, imaginative content generation and development. Initially the branch has been started with the degree of BFA/MFA and later-on the branch of Fine Arts offered with the specializations viz. Architecture/ Cartooning/ Dance etc.

In a recent move and educational experiments universities have started the Multimedia and Allied Technologies
Table: 3-Private Universities and Multimedia/ Allied

Technologies (in Engineering \& Technology Track)

\begin{tabular}{|c|c|c|}
\hline S.. & \multicolumn{2}{|c|}{$\begin{array}{l}\text { Private Universities in India offering Multimedia } \\
\text { \& Allied Technologies Programs with Engineering } \\
\text { Track }\end{array}$} \\
\hline $\mathbf{1}$ & $\begin{array}{c}\text { Shree Guru Gobind Singh } \\
\text { Tricentenary University, } \\
\text { Haryana }\end{array}$ & $\begin{array}{c}\text { BTech-CSE ( Animation } \\
\text { \& Games) }\end{array}$ \\
\hline $\mathbf{2}$ & $\begin{array}{c}\text { Eternal University, Himachal } \\
\text { Pradesh }\end{array}$ & $\begin{array}{c}\text { BTech-CSE (Computer } \\
\text { Animations) }\end{array}$ \\
\hline $\mathbf{3}$ & Galgotias University, UP & $\begin{array}{c}\text { BTech (H)-CSE (Graphics } \\
\text { \& Gaming) }\end{array}$ \\
\hline $\mathbf{4}$ & Invertis University, UP & $\begin{array}{c}\text { BTech-CSE (Animation \& } \\
\text { VFX) }\end{array}$ \\
\hline $\mathbf{5}$ & University of Petroleum and & $\begin{array}{c}\text { BTech-CSE (Graphics \& } \\
\text { Gaming) }\end{array}$ \\
\hline $\mathbf{6}$ & Energy Studies, UK & MTech-Web \& Game \\
& & Designing \\
\hline
\end{tabular}

specially the Animation etc within the Degree of BFA. A detailed on this with the name of the universities and programs etc (including Designing field) have been provided in Table: 5. Moreover Table: 4 depicted in details with the name of the universities, their territory and the programs in the Multimedia and Allied Technologies offering programs other than common Science and Arts track.

It is a great move by the private universities of introducing the latest and emerging Multimedia and Allied Technologies within the field and program of Designing, Fine Arts and also creating this is as an important branch of Engineering and also as a specialization of Computer Science and Engineering.

This study already reveals that Computer Application is an important branch within 'Computing' track and conceptualized, developed and still available only in India. But it is only concentrated with Software Technologies/ Field, when rest of the world started different applied program viz. IT etc having concentration of more than IT, the Indian academics were moved into Computer Application with the degrees of BCA/MCA. Though in a latest move by the private universities is that inclusion of important IT component i.e. Multimedia and Allied Technologies within Computer Application leading to BCA degree (details are provided in Table: 4). 
Table: 4-Private Universities and Multimedia/ Allied Technologies (other than Science \& Arts)

\begin{tabular}{|c|c|c|}
\hline \multirow[t]{2}{*}{ Sl. No. } & \multicolumn{2}{|c|}{$\begin{array}{l}\text { Private Universities in India offering Multimedia \& Allied Technologies Programs (Other } \\
\text { than BA/BSc \& MAV MSc) }\end{array}$} \\
\hline & Universities & Programs \\
\hline 1 & $\begin{array}{c}\text { Shree Guru Gobind Singh Tricentenary } \\
\text { University, Haryana }\end{array}$ & BTech-CSE ( Animation \& Games) \\
\hline 2 & Eternal University, Himachal Pradesh & BTech-CSE (Computer Animations) \\
\hline 3 & $\begin{array}{l}\text { M.S. Ramaiah University of Applied Sciences, } \\
\text { Karnataka }\end{array}$ & M.Des (Computer Animation \& Game Design) \\
\hline 4 & Jagran Lakecity University, Madhya Pradesh & BFA ( Digital Film Making \& VFX) \\
\hline 5 & Sandip University, Maharashtra & BFA (Animation \& VFX) \\
\hline 6 & C.T University, Punjab & B. Design (Multimedia) \\
\hline 7 & Lovely Professional University, Punjab & $\begin{array}{c}\text { B. Design (Multimedia) } \\
\text { B. Design (Computer Graphics) }\end{array}$ \\
\hline 8 & Poornima University, Rajasthan & BFA (Animation \& VFX) \\
\hline 9 & Amity University, UP & BFA (Animation) \\
\hline 10 & Galgotias University, UP & $\begin{array}{c}\text { BCA (Animation \& Multimedia)/ } \\
\text { BTech (H)-CSE (Graphics \& Gaming) }\end{array}$ \\
\hline 11 & Invertis University, UP & BTech-CSE (Animation \& VFX) \\
\hline 12 & Swami Vivekanand Subharti University, UP & BFA (Animation) \\
\hline 13 & Himgiri Zee University, UK & B.Voc ( 3D Animation \& Visual Effects) \\
\hline 14 & $\begin{array}{l}\text { University of Petroleum and Energy Studies, } \\
\text { UK }\end{array}$ & $\begin{array}{c}\text { BTech-CSE } \\
\text { (Graphics \& Gaming) }\end{array}$ \\
\hline 15 & Seacom Skills University, WB & MTech-Web \& Game Designing \\
\hline 16 & CMR University & CA (Game \& Mobile App Development) \\
\hline
\end{tabular}

\section{MAJOR FINDINGS: HighLIGHTS}

- Computing and CS is concentrated with mathematical focus; computer designing and development with special focus on software technologies.

- Traditionally Fine Arts, Designing treated as a field of intellectual, imaginative content generation and development and the move of private universities regarding the integration of traditional and latest Multimedia and Allied Technologies is a remarkable educational planning and innovation.

- Indian academics started program on Software Technologies when rest of the world started different applied programs viz. IT but India were moved into Computer Application with the degrees of BCA/MCA and Multimedia Technologies also been started as a specializations of this degree. Still two Universities namely CMR University and Galgotias University started BCA with this but a specialization may be offered at the MCA Degree.
- It is reveals by the study that Multimedia and Allied Technologies now as full-fledged field and academic program and a large number of universities have started the field within the track Science/Arts. As per the study forty (40) universities have offered the program. While Engineering and Technology grab five (5) program in the field.

- As far as the study it has noticed that a majority (say about all) of the program are from the Science with direct concentration rather specialization or major of 'Computing and Information' branch (Refer Table: $6)$.

- It has also observed that a university started a different and emerging program with the degree of Vocational stream with B.Voc. (details in depicted in Table: 6).

Table: 5- Multimedia and Allied Technologies in Designing and Fine Arts track 


\begin{tabular}{|c|c|c|}
\hline Sl. No. & $\begin{array}{l}\text { Private Universities in India offering } \\
\text { Designing \& Fine Arts Track }\end{array}$ & nedia \& Allied Technologies Programs in \\
\hline & Universities & Programs \\
\hline 1 & $\begin{array}{l}\text { M.S. Ramaiah University of Applied Sciences, } \\
\text { Karnataka }\end{array}$ & M.Des (Computer Animation \& Game Design) \\
\hline 2 & Jagran Lakecity University, Madhya Pradesh & BFA ( Digital Film Making \& VFX) \\
\hline 3 & Sandip University, Maharashtra & BFA (Animation \& VFX) \\
\hline 4 & C.T University, Punjab & B. Design (Multimedia) \\
\hline 5 & Lovely Professional University, Punjab & $\begin{array}{l}\text { B. Design (Multimedia) } \\
\text { B. Design (Computer Graphics) }\end{array}$ \\
\hline 6 & Poornima University, Rajasthan & BFA (Animation \& VFX) \\
\hline 7 & Amity University, UP & BFA (Animation) \\
\hline 8 & Swami Vivekanand Subharti University, UP & BFA (Animation) \\
\hline
\end{tabular}

Table: 6-Private Universities and growing trend in Multimedia Technologies into different field/subject Sl. No. $\quad$ Private Universities in India offering Multimedia \& Allied Technologies Programs in Designing \& Fine Arts Track

\begin{tabular}{|l|c|c|}
\hline & Track \& Level (UG \& PG) & In Numbers \\
\hline $\mathbf{1}$ & Science & 40 \\
\hline $\mathbf{2}$ & Arts & 04 \\
\hline $\mathbf{3}$ & Technology/ Engineering & 05 \\
\hline $\mathbf{4}$ & Designing & 06 \\
\hline $\mathbf{5}$ & Fine Arts & 05 \\
\hline $\mathbf{6}$ & Vocational & 01 \\
\hline $\mathbf{7}$ & Computer Application & 02 \\
\hline
\end{tabular}

\section{CONCLUSION}

Multimedia and Allied Technologies is rapidly growing within the field of Computing and Information Technology. Initially Multimedia were treated as a technology for text, audio, video, image, contents, animation etc and gradually it has become an important branch of IT. But the development and progress of education systems, science and technology and their requirement in the diverse field lead it is as a program as well in renowned international universities. To see the changing trend and importance many Indian Universities specially private universities are taken initiative to introduce and incorporate Multimedia and Allied Technologies as a branch with specialization, major and concentration in different educational subjects. Significantly the field Multimedia and Allied Technologies not only introduced as a full-fledged field or a major within Multimedia and Allied Technologies but also in a subjects like fine arts or designing due to possibilities of linkages etc. It has noted with the study that BFA and BCA are already have Multimedia and Allied Technologies as a concentration but Masters of these field not yet started with this concentration and thus there is a great potentiality to introduce this stream for the interested learner and professional with difference. Moreover other universities may start the program with possible collaboration and tie-up etc with the industries, organizations and institutions etc. 


\section{REFERENCES}

[1] Bhavani, B., Sheshadri, S., \& Unnikrishnan, R. (2010, September). Vocational education technology: rural India. In Proceedings of the 1st Amrita ACM-W Celebration on Women in Computing in India (p. 21). ACM.

[2] Cheng, L. I., Basu, A., \& Goebel, R. (2009). Interactive Multimedia for Adaptive Online Education. IEEE MultiMedia, 16(1), 16-25.

[3] Desai, S., \& Kulkarni, V. (2008). Changing educational inequalities in India in the context of affirmative action. Demography, 45(2), 245-270.

[4] Ellis, T. (2004). Animating to build higher cognitive understanding: A model for studying multimedia effectiveness in education. Journal of Engineering Education, 93(1), 59-64.

[5] García, R. R., Quirós, J. S., Santos, R. G., González, S. M., \& Fernanz, S. M. (2007). Interactive multimedia animation with macromedia flash in descriptive geometry teaching. Computers \& Education, 49(3), 615-639.

[6] Gereffi, G., Wadhwa, V., Rissing, B., \& Ong, R. (2008). Getting the numbers right: International engineering education in the United States, China, and India. Journal of Engineering Education, 97(1), 13-25.

[7] Gupta, D., \& Gupta, N. (2012). Higher education in India: structure, statistics and challenges. Journal of education and Practice, 3(2).

[8] Bhattacharya, I., \& Sharma, K. (2007). India in the knowledge economy-an electronic paradigm. International Journal of Educational Management, 21(6), 543-568.

[9] Mahajan, G. (2012). Multimedia in teacher education: Perceptions \& uses. Journal of Education and Practice, 3(1), 5-13.

[10] Paul, P.K. and Bhuimali, A. and Aithal, P. S., Indian Higher Education: With Slant to Information Technology- a Fundamental Overview. International Journal on Recent Researches In Science, Engineering \& Technology, 5(11), 31-50.

[11] Paul, P.K. and P.S. Aithal, Bachelor of Computer Applications (BCA): An Applied Science Program into a New Direction? Educational Quest: An Int. J. of Education and Applied Social Science: 8(4), 1-9

[12] Paul, P.K., P.S. Aithal, A. Bhuimali, K. Kumar, Emerging Degrees and Collaboration: The Context of Engineering Sciences in Computing \& IT - An Analysis for Enhanced Policy Formulation in India International Journal on Recent Researches In Science, Engineering \& Technology, 5(12), 13-27, (Indexed in Google Scholar, DIIF, SJIF). (UGC Serial Number: 45483)

[13] Paul, P.K., A. Bhuimali, P.S. Aithal and Rajesh, R., Bachelor's Degree in Computing and Allied Fields in India Emphasizing Private Universities - A Study of Science Platform (BCA \& $\mathrm{BSc}$ ). International Journal on Recent Researches in Science, Engineering \& Technology, Vol. 5(12), p. 1-12, (Indexed in Google Scholar, DIIF, SJIF). (UGC Serial Number: 45483)
[14] Tate, D. S., \& Schwartz, C. L. (1993). Increasing the retention of American Indian students in professional programs in higher education. Journal of American Indian Education, 21-31.

[15] Tayade, M. C., \& Kulkarni, N. B. (2011). The Interface of technology and medical education in india: current trends and scope. Indian Journal of Basic \& Applied Medical Research, 1(1), 8-12.

[16] Umashankar, V., \& Dutta, K. (2007). Balanced scorecards in managing higher education institutions: an Indian perspective. International Journal of Educational Management, 21(1), 54-67. 